\title{
Hubungan Motivasi Terhadap Kinerja Karyawan Pada Bank Pembangunan Daerah Jawa Barat Dan Banten Tbk. (Bank Bjb) Cabang Bsd - Tangerang Selatan
}

\author{
Hadi Winata \\ Dosen Fakultas Ekonomi Universitas Pamulang \\ Email : dosen00326@unpam.ac.id
}

\begin{abstract}
ABSTRAK
Tujuan dari penelitian ini adalah untuk mengetahui hubungan motivasi terhadap kinerja karyawan pada Bank Pembangunan Daerah Jawa Barat Dan Banten Tbk. (Bank bjb) Cabang Bsd - Tangerang Selatan.

Metode dalam penelitian ini penulis menggunakan metode kuantitatif yang merupakan pendekatan, penilaian berdasarkan angka dengan menggunakan hitungan statistik, dan waktu penelitian dilakukan selama 5 bulan. Sempel dan dengan populasi jadi dalam penelitian ini 80 responden. Teknik pengumpulan data, dalam penelitian ini menggunakan teknik riset kepustakaan, riset lapangan, observasi, kuesioner dan wawancara. Sedangkan analisis data dalam penelitian ini menggunakan metode kuantitatif yang mempunyai ciri dapat dinilai dengan menggunakan angka dan menggunakan metode uji validitas, reliabilitas koefisien determinasi dan uji signifikan hipotesis pada $a=5 \%$.

Hasil penelitian yang diperoleh menunjukan dengan adanya hubungan yang signifikan antara variabel motivasi terhadap kinerja karyawan pada Hubungan Motivasi Terhadap Kinerja Karyawan Pada Bank Pembangunan Daerah Jawa Barat Dan Banten Tbk. (Bank bjb) Cabang Bsd - Tangerang Selatan, melalui perhitungan koefisien korelasi diketahui determinasi di peroleh 0.8215 di katagorikan sedang. Dan perhitungan koefisien determinasi diperoleh $67.48 \%$. hal ini menunjukan bahwa besarnya hubungan motivasi tehadap kinerja karyawan sebesar $67.48 \%$ dan $32.52 \%$ sisanya oleh faktor - faktor yang tidak diteliti dalam penelitian ini. Berdasarkan hasil uji hipotesis hasil $\mathrm{T}_{\text {hitung }}$ juga memiliki nilai yang lebih besar dari $\mathrm{T}_{\text {tabel }} 12.722>1.991$ yang artinya Ho ditolak dan Ha diterima. Maka dapat disimpulkan terdapat hubungan motivasi $(\mathrm{X})$ terhadap kinerja $(\mathrm{Y})$.
\end{abstract}

\section{Kata Kunci : Motivasi Kerja dan Kinerja Karyawan}




\section{PENDAHULUAN}

\section{A. Latar belakang}

Pada umumnya setiap perusahaan akan selalu berusaha mencapai tujuan yang telah ditetapkan. Dalam usahanya mencapai tujuan inilah perusahaan seringkali di hadapkan pada berbagai masalah, baik yang internal maupun eksternal, juga yang bersifat finansial/non finansial. Masalahmasalah tersebut saling terkait satu sama lain di mana pada akhirnya halhal tersebut memaksa organisasi atau badan usaha untuk cepat dan tanggap dalam mengatasinya. Karyawan merupakan asset utama organisasi dan mempunyai peran yang strategis didalam organisasi yaitu sebagai pemikir, perencana dan pengendali aktivitas organisasi.Demi tercapainya tujuan organisasi, karyawan memerlukan motivasi untuk bekerja lebih rajin.Melihat pentingnya karyawan dalam organisasi, maka karyawan diperlukan perhatian lebih serius terhadap tugas yang dikerjakan sehingga tujuan organisasi tercapai.

Dengan motivasi kerja yang tinggi, karyawan akan bekerja lebih giat didalam melaksanakan pekerjaannya. Sebaliknya dengan motivasi kerja yang rendah karyawan tidak mempunyai semangat bekerja, mudah menyerah, dan kesulitan dalam menyelesaikan pekerjaannya. Karyawan kurang memiliki informasi yang jelas apakah pekerjaan mereka memiliki dampak positif terhadap para penerima manfaatnya, yaitu individu atau kelompok yang dilayani organisasi.Signifikasi tugas seringkali tidak pasti di organisasi organisasi karena beberapa alasan.Pertama, Karyawan diorganisasi sering menemui perasangka buruk, yang bisa menghalangi mereka untuk merasa bahwa mereka telah mencapai tujuan - tujuan dan membuat mereka ragu apakah misi mereka adalah mungkin.Kedua, para karyawan seringkali hanya menerima umpan balik langsung yang sedikit tentang bagaimana tindakan - tindakan mereka mempengaruhi penerima manfaat, yang mungkin membuat ragu apakah misi mereka tercapai atau tidak.

Manajeman kinerja adalah proses menyeluruh untuk mengamati kinerja sesorang karyawan dalam hubungannya dengan persyaratan jabatan selama jangka waktu tertentu (yakni, menjelaskan, menetapkan tujuan, memberikan bimbingan langsung tentang bagaimana melakukan pekerjaan, menyimpan dan mengakses informasi entang kinerja) dan kemudian membuat penilaiana tentang kinerja itu.

Mengingat pentingnya masalah tersebut maka penulis melakukan penelitian ini agar dapat memberikan manfaat bagi organisasi dalam memberikan motivasi kepada karyawan sehingga tujuan organisasi dapat tercapai.Berdasarkan uraian latar belakang tersebut di atas, maka di ajukan penelitian dengan judul "Hubungan Motivasi Karyawan Terhadap Kinerja Pada Bank Pembangunan Daerah Jawa Barat Dan Banten Tbk. (Bank bjb) Cabang BSD - Tangerang Selatan".

\section{B. Identifikasi Masalah}

Setiap perusahaan menginginkan agar karyawan mau bekerja sesuai dengan aturan yang berlaku dalam bekerja, sehingga 
perusahaan dituntut untuk mampu memberikan motivasi kepada karyawannya untuk bekerja sesuai aturan dan kinerja yang dimaksud agar sesuai dengan yang diharapkan sebelumnya, tapi tidak semua perusahaan berhasil dalam melaksanakan hal tersebut. Berdasarkan uraian tersebut, maka penulis mengidentifikasi masalah sebagai berikut :

1. Karyawan tidak mempunyai semangat kerja dalam bekerja pada Bank bjb Cabang BSD Tangerang Selatan.

2. Karyawan sering kesulitan menyelesaikan pekerjaannya sesuai dengan waktu yang ditentukan pada Bank bjb Cabang BSD - Tangerang Selatan.

3. Karyawan diorganisasi sering menemmui perasangka buruk pada Bank bjb Cabang BSD Tangerang Selatan.

4. Karyawan tidak mengerti job desk pada Bank bjb Cabang BSD - Tangerang Selatan.

5. Karyawan masih kurang pengawasan pada Bank bjb Cabang BSD - Tangerang Selatan.

\section{Pembatasan Masalah}

Pada penelitian kali ini penulis membatasi masalah yang akan diteliti pada peningkatan motivasi karyawan terhadap kinerja.

1. Kinerja merupakan suatu kondisi yang harus diketahui dan dikonfirmasikan kepada pihak tertentu untuk mengetahui tingkat pencapaian hasil suatu instansi dihubungkan dengan visi yang diemban suatu organisasi atau perusahaan serta mengetahui dampak positif dan negatif dari suatu kebijakan operasional.

2. Motivasi kerja adalah kondisi atau keadaan dalam suatu perusahaan yang ingin meningkatkan keuntungan yang lebih besar dari sebelumnya, maka dari itu motivasi kerja sangat berperan penting dalam mendapat produktivitas yang maksimal.Karena tujuan dari motivasi kerja adalah memberikan semangat kerja kepada setiap karyawan agar karyawan dapat melaksanakan tugasnya secara efektif dan efisen.

3. Penelitian dilaksanakan di Bank bjb Cabang BSD Tangerang Selatan.

4. Waktu Penelitian mulai tanggal 1 Januari sampai dengan 31 Maret 2018.

\section{Rumusan Masalah}

Berdasarkan pembatasan masalah maka penulis merumusakan masalah sebagai berikut:

1. Bagaimana motivasi pada Bank bjb Cabang BSD Tangerang Selatan?

2. Bagaiaman kinerja pada Bank bjb Cabang BSD - Tangerang Selatan?

3. Seberapa besar hubungan motivasi terhadap kinerja karyawan pada Bank bjb Cabang BSD - Tangerang Selatan?

\section{G. Kerangka Berpikir}

Kerangka berpikir merupakan model konseptual bagaimana teori 
berhubungan dengan berbagai faktor yang telah diidentifikasi sebagai masalah yang penting. (Sugiyono, 2011:60)
Maka dapat disusun suatu kerangka pemikiran dalam peneilitian ini, seperti yang di terapkan dalam gambar berikut ini :

\section{Hubungan Motivasi Terhadap Kinerja Karyawan Pada Bank Bank Pembangunan Daerah Jawa Barat dan Banten Tbk (Bank bjb) Cabang BSD - Tangerang Selatan}

\begin{tabular}{|l|l|}
\hline \multicolumn{1}{|c|}{ MOTIVASI } & \multicolumn{1}{|c|}{ KINERJA } \\
\hline a. Lingkungan Kerja & \\
b. Jaminan & a. Kualitas \\
c. Komunikasi & b. Kuantitas \\
d. Pekerjaaan & c. Ketepatan Waktu \\
e. Penghargaan & d. Tanggung Jawab \\
& e. Pelatihan \\
\hline
\end{tabular}

Sumber: Siagian, 2013:49

Sumber: Mangkunegara, 2015:67

\section{Gambar 1.1}

Kerangka berpikir

\section{H. Hipotesis}

Hipotesis merupakan jawaban sementara terhadap rumusan masalah penelitian, dimana rumusan masalah penelitian telah dinyatakan dalam bentuk kalimat pernyataan. Sugiyono, (2011:63)

Hipotesis merupakan anggaran dasar yang kemudian membuat suatu teori yang harus diuji kebenarannya.

Adapun hipotesis penelitian ini adalah :

$H_{0}=$ diduga tidak terdapat hubungan motivasi terhadap kinerja.

$H_{1}=$ diduga terdapat hubungan motivasi terhadap kinerja.

\section{LANDASAN TEORI}

\section{A. Manajemen}

Manajemen berasal dari kata to manage yang artinya mengatur.
Pengaturan dilakukan melalui proses dan atur berdasarkan urutan dari fungsi-fungsi manajeman itu. Jadi, manajemen itu merupakan suatu proses untuk mewujudkan tujuan yang diinginkan.

Menurut Hasibuan (2011 : 2), Manajemen adalah ilmu dan seni mengatur proses pemanfaatan sumber daya manusia dan sumber-sumber lainnya secara efektif dan efisien untuk mencapai tujuan tertentu.

\section{B. Manajemen Sumber Daya Manusia \\ Manusia selalu berperan aktif} dan dominan dalam setiap kegiatan organisasi, karena manusia menjadi perencanaan, perilaku, dan penentu terwujudnya tujuan organisasi. Tujuan tidak mungkin terwujud tanpa 
peran aktif karyawan meskipun alatalat yang dimiliki perusahaan begitu canggihnya. Alat-alat canggih yang dimiliki perusahaan tidak ada manfaatnya bagi perusahaan. Jika peran aktif karyawan tidak diikutsertakan. Mengatur karyawan adalah sulit dan kompleks, karena mereka mempunyai pikiran, perasaan status, keinginan, dan latar belakang yang heterogen yang dibawa ke dalam organisasi. Karyawan tidak dapat diatur dan dikuasai sepenuhnya seperti mengatur mesin, modal, atau gedung.

Berikut pengertian manajemen sumber daya manusia (MSDM) menurut beberapa pakar sumber daya manusia.

Menurut Marihot Tua dalam Sunyoto (2015 : 1). Manajemen sumber daya manusia adalah aktivitas yang dilakukan merangsang, mengembangkan, memotivasi, dan memelihara kinerja yang tinggi dalam organisasi.

\section{Motivasi}

Menurut Hasibuan (2011:218), Motivasi adalah suatu perangsang keinginan (want) dan daya penggerak kemauan bekerja seseorang. Setiap motif mempunyai tujuan tertentu.

Menurut Drs. Moekijat dalam Hasibuan (2011:218), Motivasi adalah suatu pengertian yang mengandung semua alat penggerak alasasn-alasan atau dorongandorongan dalam diri manusia yang menyebabkan ia berbuat sesuatu.

Menurut Sutrisno (2016:109), Motivasi adalah suatu faktor yang mendorong seseorang untuk melakukan aktivitas tertentu, oleh karena itu motivasi sering kali diartikan pula sebagai faktor pendorong perilaku seseorang.

\section{Kinerja}

Dalam dunia yang diwarnai kompetisi global, khusunya dalam aspek ekonomi dan bisnis, perusahaan-perusahaan

membutuhkan kinerja tinggi dari semua karyawannya. Pada saat yang sama, para karyawan membutuhkan umpan balik atas kinerja mereka sebagai pedoman bagi peningkatan perilaku kerja di masa yang akan datang. Kebutuhan ini terutama tampak sangat menonjol dikalangan pekerja baru, yang sedang mencoba untuk memahami pekerjaan dan tempat kerja mereka. Para pekerja dengan masa kerja yang lama juga menginginkan umpan balik positif atas hal-hal baik yang mereka kerjakan. Atas umpan balik korektif yang mereka terima, para karyawan mungkin akan merasa keberatan. Tetapi, umpan balik seperti ini pun akan membawa manfaat bagi karyawan dan, pada gilirannya, juga bagi organisasi.

Para manajer harus mengevaluasi kinerja agar dapat mengetahui tindakan atau langkahlangkah apa yang harus diambil selanjutnya. Umpan balik spesifik dapat membantu mereka dalam melakukan perencanaan karir, pelatihan dan pengembangan, peningkatan gaji, promosi, dan berbagai keputusan lainnya. Divisi atau departemen SDM menggunakan informasi yang di peroleh dari penilaian kinerja untuk mengevaluasi keberhasilan program rekrutmen, seleksi, orientasi, penempatan, pelatihan, dan berbagai aktivitas lainnya. 
Menurut Marwansyah (2012:228). Kinerja adalah pencapaian/prestasi seseorang berkenaan dengan tugas-tugas yang dibebankan kepadanya. Kinerja juga pula dipandang sebagai perpaduan dari hasil kerja (apayang harus dicapai seseorang) dan kompetensi (bagaimana seseorang mencapainya).

\section{METODOLOGI PENELITIAN}

Metode dalam penelitian ini penulis menggunakan metode kuantitatif yang merupakan pendekatan, penilaian berdasarkan angka dengan menggunakan hitungan statistik, dan waktu penelitian dilakukan selama 5 bulan. Sempel dan dengan populasi jadi dalam penelitian ini 80 responden. Teknik pengumpulan data, dalam penelitian ini menggunakan teknik riset kepustakaan, riset lapangan, observasi, kuesioner dan wawancara. Sedangkan analisis data dalam penelitian ini menggunakan metode kuantitatif yang mempunyai ciri dapat dinilai dengan menggunakan angka dan menggunakan metode uji validitas, reliabilitas koefisien determinasi dan uji signifikan hipotesis pada $\mathrm{a}=5 \%$.

\section{HASIL PENELITIAN DAN PEMBAHASAN}

\section{Deskripsi Responden}

Responden yang diambil adalah semua karyawan pada Bank bjb Cabang BSD - Tangerang Selatan, yang aktif bekerja dengan sampel berjumlah 80 orang, sehingga dari penyebaran kuesioner yang dilakukan penliti mendapatkan penulaian atau jawaban yang beragam dan dapat di gambarkan karakteristik reponden tersebut sebagao berikut : a. Responden Menurut Jenis Kelamin Responden

Responden menurut jenis kelamin dalam penelitian ini dikelompokan menjadi 2 (dua) macam kelompok yaitu jenik lemain perempuan dan jenis kelamin laki-laki. Data mengenai jeni kelamin responden ini adalah sebagai berikut

Table 4.1

Jenis Kelamin Responden

\begin{tabular}{|c|c|c|c|}
\hline $\begin{array}{c}\mathrm{N} \\
\mathrm{o}\end{array}$ & $\begin{array}{c}\text { Jenis } \\
\text { kelamin }\end{array}$ & $\begin{array}{c}\text { Jumla } \\
\mathrm{h} \\
\text { (orang } \\
\text { ) }\end{array}$ & $\begin{array}{c}\text { Presentas } \\
\mathrm{e}(\%)\end{array}$ \\
\hline 1 & Laki-laki & 37 & $46,25 \%$ \\
\hline 2 & $\begin{array}{c}\text { Perempua } \\
\mathrm{n}\end{array}$ & 43 & $53,75 \%$ \\
\hline \multicolumn{2}{|c|}{ jumlah } & 80 & $100 \%$ \\
\hline
\end{tabular}

Sumber : Data olahan kuesioner, 2018

Berdasarkan table jenis kelamin menunjukana dari 80 responden yang jumlah frekuensi responden perempuan paling banyak dalam penelitian ini adalah 43 orang $(58,24 \%)$ dan responden laki-laki adalah sebanyak 37 orang $(41,76 \%)$.

b. Responden Menurut Tingkat Pendidikan

Responden menurut tingkat pendidikan di dalam penelitian ini terbagi menjadi 4 (empat) kelompok tingakt pendidikan. Data mengenai tingkat pendidikan repsonden adalah sebagai berikut :

Table 4.2

Pendidikan Responden

\begin{tabular}{|c|c|c|c|}
\hline $\begin{array}{c}\text { N } \\
\text { o }\end{array}$ & $\begin{array}{c}\text { Tingkat } \\
\text { peendidik } \\
\text { an }\end{array}$ & $\begin{array}{c}\text { Jumla } \\
\text { h }\end{array}$ & $\begin{array}{c}\text { Presenta } \\
\text { se (\%) }\end{array}$ \\
\hline 1 & Smu/smk & 9 & $11,25 \%$ \\
\hline 2 & Diploma & 20 & $25 \%$ \\
\hline 3 & Sarjana 1 & 40 & $50 \%$ \\
\hline 4 & Sarjana 2 & 11 & $13,75 \%$ \\
\hline \multicolumn{2}{|c|}{ Jumlah } & 80 & $100 \%$ \\
\hline
\end{tabular}


Sumber : Data Olahan Kuesioner, 2016

Berdasarkan tabel pendidikan menunjukan bahwa daro 80 responden yang jumlah frekuensi responden yang tingkat pendiidkan paling tinggi adalah Sarjana 1 yaitu sebnyak 40 orang $(50 \%)$, responden yang tingkat pendidikannya Diploma adalah sebanyak 20 orang $(25 \%)$, responden yang tingkat pendidikannya Sarjana 2 adalah sebanyak 11 orang $(13,75 \%)$, selanjutnya respondne yang tingkat pendidikannya SMU/SMK adalah 9 orang $(11,25 \%)$.

c. Responden Menurut Tingkat Usia

Responden menurut tingkat usia dalam penelitian ini di klopmpokan menjadi 3 (tiga) kelompok usia. Data mengenai usia reponden adalah sebagai berikut :

Tabel 4.3

Usia Responden

\begin{tabular}{|c|c|c|c|}
\hline $\begin{array}{c}\text { N } \\
\text { o }\end{array}$ & $\begin{array}{c}\text { Kelompo } \\
\text { k usia }\end{array}$ & $\begin{array}{c}\text { Jumla } \\
\mathrm{h}\end{array}$ & $\begin{array}{c}\text { Presentas } \\
\text { e (\%) }\end{array}$ \\
\hline 1 & $20-30$ & 20 & $25 \%$ \\
\hline 2 & $31-40$ & 35 & $43,75 \%$ \\
\hline 3 & $41-50$ & 25 & $31,25 \%$ \\
\hline \multicolumn{2}{|c|}{ Jumlah } & 80 & $100 \%$ \\
\hline
\end{tabular}

Sumber : data olahan kuesioner, 2018

Berdasarkan tabel usai frekuensi responden menunjukan bahwa dari 80 responden yang jumlah frekuensi usia responden yang paling bnyak dalam penelitian ini adalh responden yang berusia 31 - 40 tahun yaitu sebanyak 35 orang $(43,75 \%)$, responden yang berusia antar 41 - 50 tahun yaitu sebanyak 25 orang $(31,25 \%)$ dan responden yang berusia antara $20-30$ tahun yaitu sebanyak 20 orang (25\%).

d. Responden Menurut Lama Bekerja Di Perusahaan
Lama bekerja responden di dalam perusahaan ini di kelompokan menjadi 2 kelompok. Data mengenai lama bekerja responden di Bank bjb Cabang BSD - Tangerang Selatan adalah sebagai berikut :

Tabel 4.4

Lama bekerja responden di perusahaan

\begin{tabular}{|c|c|c|c|}
\hline No & $\begin{array}{c}\text { Lama } \\
\text { bekerja }\end{array}$ & Jumlah & $\begin{array}{c}\text { Presentase } \\
(\%)\end{array}$ \\
\hline 1 & $\begin{array}{l}1-5 \\
\text { tahun }\end{array}$ & 30 & $37.5 \%$ \\
\hline 2 & $\begin{array}{l}5-10 \\
\text { tahun }\end{array}$ & 50 & $62,5 \%$ \\
\hline \multicolumn{2}{|c|}{ Jumlah } & 80 & $100 \%$ \\
\hline
\end{tabular}

Sumber; Data olahan kuesioner, 2018

Berdasarkan tabel lama bekerja responden menunjukan bahwa dari 80 responden yang jumlah frekuensi responden yang paling lama masa kerjanya adalah responden yang lama kerjanya 5 - 10 tahu $(62,5 \%)$ dan responden yang lama kerjanya antara $1-5$ tahun yaitu sebanyak 30 orang $(37,5 \%)$.

\section{Hasil penelitian}

\section{a. Uji Validitas dan Reliabilitas Varibael Motivasi (X) \\ 1) Uji Validitas Variabel Motivasi (X)}

Uji validitas digunakan untuk menguji pernyataan ataupun pertanyaan pada kuesioner yang didistribusikan apakah valid atau tidak valid. Untuk menentukan data yaleh dari hasil penelitian dapat di gunakan atau tidak maka penulis mengguankan uji validitas.

$\mathrm{rxy}=\frac{n \Sigma X Y-(\Sigma X)(\Sigma Y)}{\sqrt{\left[n \Sigma X i^{2}-(\Sigma X)^{2}\right\},\{n \Sigma Y 2-(\Sigma y) 2\}}}$

Perhitungannya dengan cara membandingkan nilai $r_{\text {hitung }}$ dengan 
$\mathrm{r}_{\text {tabel }}$ dengna signifikan (kesalahan) $5 \%$. Bila $r_{\text {hitung hasilnya positif dan }}$ lebih besar dari tabel $r_{\text {tabel }}$ maka butir penyataan atau pertanyaan tersebut dikatakan Diterima. Berikut adalah hasil perhitungan uji validitas variabel motivasi $(\mathrm{X})$.

Tabel 4.5 Hasil validitas variabel motivasi $(\mathbf{X})$

\begin{tabular}{|c|c|c|c|}
\hline Pernyataan & $\begin{array}{c}\text { r- } \\
\text { hitung }\end{array}$ & $\begin{array}{c}\text { r- } \\
\text { tabel }\end{array}$ & Keterangan \\
\hline 1 & 0,373 & 0,220 & Valid \\
\hline 2 & 0,391 & 0,220 & Valid \\
\hline 3 & 0,272 & 0,220 & Valid \\
\hline 4 & 0,442 & 0,220 & Valid \\
\hline 5 & 0,351 & 0,220 & Valid \\
\hline 6 & 0,480 & 0,220 & Valid \\
\hline 7 & 0,320 & 0,220 & Valid \\
\hline 8 & 0,287 & 0,220 & Valid \\
\hline 9 & 0,339 & 0,220 & Valid \\
\hline 10 & 0,363 & 0,220 & Valid \\
\hline
\end{tabular}

Dari tabel di atas dapat dilihat bahwa dari nilai keseluruhan koefisien korelasi ( $\mathrm{r}_{\text {hitung }}$ ) memiliki nilai lebih besar daripada $r_{\text {tabel }}$. Dapat disimpulkan bahwa kesepuluh butir pernyataan tersebut adalah Valid karena nilai $\mathrm{r}_{\text {hitung }}$ adalah positif dan lebih besar dari $\mathrm{r}_{\text {tabel }}$ untuk $\mathrm{n}=80$ yaitu sebesar 0,220.

Berikut adalah salah satu contoh pengujian validitas terhadap butir pernyataan nomor satu dari kuesioner variabel Motivasi.

$$
\begin{aligned}
& \mathrm{r}_{\mathrm{xy}}=\frac{n \Sigma X Y-(\Sigma x)(\Sigma Y)}{\sqrt{\left[n \Sigma x^{2}-(\Sigma x)^{2}\right\} \cdot\left\{n \Sigma y^{2}-(\Sigma y)^{2}\right\}}} \\
& \mathrm{r}_{\mathrm{xy}}=\frac{2422}{6497.4459} \\
& \mathrm{r}_{\mathrm{xy}}=0.373
\end{aligned}
$$

Keterangan : maka $r_{\text {hitung }}>r_{\text {tabel }}$ atau $0.373>0.220$ dengan ketentuan $\alpha=$ $5 \%$ dengan besar $r_{\text {tabel }}=0.220$ maka varian butir pernyataan no. 1 variabel motivasi $(\mathrm{X})$ valid.

2) Uji Reliabilitas Variabel Motivasi (X)

Disamping uji validitas terhadap setiap intrumen, peneliti juga melakukan uji reliabilitas dengan tujuan untuk mengatahui apakah instrument yang digunakan oleh peniliti memiliki nilai yang tetap bila instrumen tersebut digunakan berulang oleh siapa dan kapan saja pada tempat penelitian yang sama.

Suatu instrumen dikatakan reliable jika nilai reliabilitas lebih dari $r_{\text {tabel }}$. Setiap variabel diterjemahkan ke dalam 10 butir pernytaan sebagai mana terlihat pada tabel di bawah ini. Hasil perhitungan bilai varian butir adalah :

Tabel 4.6

Nilai varian butir variabel motivasi $(\mathrm{X})$

\begin{tabular}{|c|c|}
\hline Pernyataan & Varian \\
\hline 1 & 0.254 \\
\hline 2 & 0.223 \\
\hline 3 & 0.236 \\
\hline 4 & 0.231 \\
\hline 5 & 0.558 \\
\hline 6 & 0.469 \\
\hline 7 & 0.252 \\
\hline 8 & 0.224 \\
\hline 9 & 0.224 \\
\hline 10 & 0.337 \\
\hline Total varian & $\mathbf{3 . 0 0 8}$ \\
\hline Sumber $:$ & data olahan \\
\hline
\end{tabular}

kuesioner, 2018

Cara perhitungan nilai di atas sebagai berikut :

a) Mencari varian butir

Dari data no 1 variabel motivasi (X) di ketahui :

$\sum \mathrm{X}_{\mathrm{i}}{ }^{2}=1357$
$\mathrm{X}_{\mathrm{i}}{ }^{2}=327$
$\mathrm{n}=80$ 
Maka semua data yang di ketahui di atas di masukkan ke dalam rumus :

St $=\frac{\sum X_{i}^{2}-\frac{(\Sigma X)^{2}}{n}}{n}$

St $=\frac{1357-\frac{(327)^{2}}{80}}{80}$

St $=\frac{20.3875}{80}$

St $=0.25484375$

Berdasarkan perhitungan di tas dapat diketahu nilai varian butir pada butir variabel Motivasi (X) no.1 adalah 0.255 (dibulatkan).

b) Menjumlahkan seluruh varian dan dari hasil penjumlahan varian butir didapat jumlah varian butir 2.996 .

c) Menghitung varian total :

Dari data mo 1 variabel motivasi (X) diketahui :

$\sum \mathrm{S}_{\mathrm{t}}{ }^{2}=139268$

$\mathrm{St}^{2}=3334$

$\mathrm{n}=80$

Maka semua data yang diketahui di atas di masukan ke dalam rumus :

$\mathrm{St}=\frac{\Sigma S_{\mathrm{t}}^{2}-\frac{(\Sigma S t)^{2}}{n}}{n}$

$\mathrm{St}=\frac{139268-\frac{(s s 84)^{2}}{80}}{80}$

$\mathrm{St}=\frac{139268-138944,45}{80}$

$\mathrm{St}=4.0043625$

d) Mencari nilai reliable hitung, Cronbach Alpha

Diketahui :

$\mathrm{n}=10$

$\sum S \mathrm{i}^{2}=3.008$

$S t^{2}=4.0443625$

$\mathrm{r}_{11}=\frac{n}{n-1}\left|1-\frac{\sum s_{i}^{2}}{s^{2}}\right|$

$r_{11}=\frac{10}{10-1}\left|1-\frac{3.008}{4.0443625}\right|$

$\mathrm{r}_{11}=\frac{10}{9}|1-0.7437|$

$\mathrm{r}_{11}=1.1111 \times 0.2563$ $\mathrm{r}_{11}=0.2848$

Keterangan karena nilai $r_{11}>r_{\text {tabel }}$ atau $0,2880>0.220$ pada $\alpha=5 \%$ dan dengan nilai $r_{\text {tabel }}=0.220$ maka dapat dibuktikan bahwa konstruksi penyataan variabel motivasi (X) adalah reliable.

b. Uji Vliditas dan Reliabilitas Varibael Kinerja (Y)

1) Uji Validitas Variabel Kinerja (Y)

Uji validitas di gunakan unutk menguji penyataan ataupun pertanyaan pada kuesioner yang didistribusikan apabila valid atau tidak valid. Untuk menentukan data yang diperoleh dari hasil penelitan dapat digunakan atau tidak maka penulis menggunakan uji vliditas.

Perhitungannya dengan cara membandingkan nilai $r_{\text {hitung }}$ dengan $\mathrm{r}_{\text {tabel }}$ dengna signifikan (kesalahan) $5 \%$. Bila $r_{\text {hitung hasilnya positif dan }}$ lebih besar dari tabel $r_{\text {tabel }}$ maka butir penyataan atau pertanyaan tersebut dikatakan valid. Berikut adalah hasil perhitungan uji validitas variabel kinerja (Y).

\section{Tabel 4.7}

\section{Hasil validitas variabel kinerja (Y)}

\begin{tabular}{|c|c|c|c|}
\hline Pernyataan & $\begin{array}{c}\text { r- } \\
\text { hitung }\end{array}$ & $\begin{array}{c}\text { r- } \\
\text { tabel }\end{array}$ & Keterangan \\
\hline 1 & 0,382 & 0,220 & Valid \\
\hline 2 & 0,540 & 0,220 & Valid \\
\hline 3 & 0,461 & 0,220 & Valid \\
\hline 4 & 0,399 & 0,220 & Valid \\
\hline 5 & 0,448 & 0,220 & Valid \\
\hline 6 & 0,383 & 0,220 & Valid \\
\hline 7 & 0,498 & 0,220 & Valid \\
\hline 8 & 0,348 & 0,220 & Valid \\
\hline 9 & 0,376 & 0,220 & Valid \\
\hline 10 & 0,605 & 0,220 & Valid \\
\hline
\end{tabular}

Sumber : data olahan kuesioner, 2018

Dari tabel di atas dapat dilihat bahwa dari nilai keseluruhan 
koefisien korelasi ( $\mathrm{r}_{\text {hitung }}$ ) memiliki nilai lebih besar daripada $r_{\text {tabel. }}$. Dapat disimpulkan bahwa kesepuluh butir pernyataan tersebut adalah Valid karena nilai $\mathrm{r}_{\text {hitung }}$ adalah positif dan lebih besar dari $\mathrm{r}_{\text {tabel }}$ untuk $\mathrm{n}=80$ yaitu sebesar 0,220.

Berikut adalah salah satu contoh pengujian validitas terhadap butir pernyataan nomor satu dari kuesioner variabel kinerja

$\mathrm{r}_{\mathrm{xy}}=\frac{n \Sigma X Y-(\Sigma X)(\Sigma Y)}{\sqrt{\left[n \Sigma x^{2}-(\Sigma x)^{2}\right\} \cdot\left\{n \Sigma y^{2}-(\Sigma y)^{2}\right\}}}$

$r_{x y}=\frac{3376}{8831.4492}$

$r_{x y}=0.382$

Keterangan : maka $r_{\text {hitung }}>r_{\text {tabel }}$ atau $0.4366>0.220$ dengan ketentuan $\alpha=5 \%$ dengan besar $\mathrm{r}_{\text {tabel }}=0.220$ maka varian butir pernyataan no. 1 variabel kinerja (Y) valid.

3) Uji Reliabilitas Variabel Kinerja (Y)

Disamping uji validitas terhadap setiap intrumen, peneliti juga melakukan uji reliabilitas dengan tujuan untuk mengatahui apakah instrument yang digunakan oleh peniliti memiliki nilai yang tetap bila instrumen tersebut digunakan berulang oleh siapa dan kapan saja pada tempat penelitian yang sama.

Suatu instrumen dikatakan reliable jika nilai reliabilitas lebih dari $r_{\text {tabel }}$. Setiap variabel diterjemahkan ke dalam 10 butir pernytaan sebagai mana terlihat pada tabel di bawah ini. Hasil perhitungan bilai varian butir adalah :

Tabel 4.8

Nilai Varian Butir Variabel Kinerja (Y)

\begin{tabular}{|c|c|}
\hline Pernyataan & Varian \\
\hline 1 & 0.274 \\
\hline
\end{tabular}

\begin{tabular}{|c|c|}
\hline 2 & 0.237 \\
\hline 3 & 0.436 \\
\hline 4 & 0.418 \\
\hline 5 & 0.329 \\
\hline 6 & 0.749 \\
\hline 7 & 0.284 \\
\hline 8 & 0.335 \\
\hline 9 & 0.414 \\
\hline 10 & 0.277 \\
\hline Total varian & $\mathbf{3 . 7 5 3}$ \\
\hline
\end{tabular}

Sumber : data olahan kuesioner, 2018

$$
\begin{aligned}
& \text { St }=\frac{\sum x_{i}^{2}-\frac{(\Sigma X)^{2}}{n}}{n} \\
& \text { St }=\frac{21.95}{80} \\
& \text { St }=0.274375
\end{aligned}
$$

Berdasarkan perhitungan di tas dapat diketahu nilai varian butir pada butir variabel kinerja (Y) no.1 adalah 0.274 (dibulatkan).

1. Menjumlahkan seluruh varian dan dari hasil penjumlahan varian butir didapat jumlah varian butir 3.753 .

2. Menghitung varian total :

Dari data mo 1 variabel kinerja (Y) diketahui :

$\sum \mathrm{S}_{\mathrm{t}}{ }^{2}=145736$

$\mathrm{St}^{2}=3408$

$\mathrm{n}=80$

Maka semua data yang diketahui di atas di masukan ke dalam rumus :

$\mathrm{St}=\frac{\sum s_{\mathrm{t}}^{2}-\frac{(\Sigma S t)^{2}}{n}}{n}$

$\mathrm{St}=6.940$

e) Mencari nilai reliable hitung, Cronbach Alpha

$\mathrm{r}_{11}=\frac{n}{n-1}\left|1-\frac{\sum s_{i}^{2}}{s^{2}}\right|$

$\mathrm{r}_{11}=0.5102$

Keterangan karena nilai $\mathrm{r}_{11}>\mathrm{r}_{\text {tabel }}$ atau $0,5102>0.220$ pada $\alpha=5 \%$ dan dengan nilai $r_{\text {tabel }}=0.220$ maka dapat dibuktikan bahwa konstruksi 
penyataan variabel kinerja (Y) adalah reliable.

\section{KESIMPULAN DAN SARAN}

\section{A. Kesimpulan}

Beradasarkan hasil penelitian dan pembahasan yang dilakukan tentang "Hubungan Motivasi Terhadap Kinerja Karyawan Pada Bank bjb Cabang BSD - Tangerang Selatan", maka hal- hal yang dapat disimpulkan penulis dalam penelitian ini adalah sebagai berikut :

1. Motivasi kerja yang ada pada Bank bjb Cabang BSD Tangerang Selatan, sudah baik. Hal ini dibuktikan dari 10 pernyataan yang diberikan kepada 80 orang responden manjawab sangat setuju sebanyak 30.25\% , "Setuju" berjumlah 64\% , "Kurang Setuju" berjumlah $4.125 \%$, "TidakSetuju" berjumlah $1.625 \%$ dan "Sangat Tidak Setuju" berjumlah $0 \%$.

2. Kinerja karyawan pada Bank bjb Cabang BSD Tangerang Selatan, sangat baik. Hasil kuesioner menunjukan sebanyak $27.75 \%$ "SangatSetuju", "Setuju" berjumlah 62.125\% , "Kurang Setuju" berjumlah $7.625 \%$, "Tidak Setuju" berjumlah 2.5\% dan "Sangat Tidak Setuju" berjumlah 0\%

3. Hubungan motivasi terhadap kinerja karyawan Bank bjb Cabang BSD - Tangerang Selatan berdasarkan uji koefisien korelasi (r) adalah 0.8215260 . hal ini menunujukan bahwa variabel motivasi memiliki hubungan yang kuat terhadap variabel kinerja karyawan. Dari hasil perhitungan koefisien determinasi $(\mathrm{KD})$ diperoleh nilai sebesar $67,48 \%$ dengan demikian dapat diketahu bahwa besarnya hubungan motivasi kerja terhadap kinerja karyawan adalah $67,48 \%$. Sedangkan $32,52 \%$ sisanya oleh faktor lain yang tidak diteliti. Berdasarkan uji hipotesis nilai $t_{\text {hitung }}(12.794)$ lebih besar dari $r_{\text {tabel }}(1.991)$, dengan taraf signifikan 5\% yang berada pada daerah penerimaan $\mathrm{H}_{\mathrm{a}}$ diterima dan $\mathrm{H}_{0}$ ditolak. Dengan demikian dapat disimpulkan bahwa motivasi mempunyai hubungan terhadap kinerja karyawan.

\section{B. Saran}

Berdasarkan hasil pembahasan dari kesimpulan mengenai hubungan motivasi terhadap kinerja karyawan pada Bank bjb Cabang BSD Tangerang Selatan.

Berikut saran-saran yang penulis sampaikan berdasarkan hasil kuisioner yang sekiranya dapat memberikan manfaat bagi pihakpihak terkait atas hasil penelitian ini. Adapun hal yang dapat disampaikan adalah sebagai berikut:

1. Pada indikator pekerjaan, pernyataan no 8 (delapan) yang menjawab tidak setuju (TS) sebanyak 5 responden atau $6.25 \%$. Dari pernyataan ini penulis dapat memberikan saran, bahwa menjalankan tugas sesuai anjuran teman dan suka 
melakukan tugas yang menantang serta pembinaan yang baik oleh perusahaan maupun pimpinan yang dapat meningkatkan loyalitas kerja harus di tingkatkan.

2. Pada indikator penghargaan, pernyataan, no 10 (sepuluh) yang menjawab tidak setuju (TS) sebanyak 4 responden atau 5\% . Dari pernyataan ini penulis dapat memberikan saran, bahwa pimpinan harus memberikan penghargaan atas prestasi yang karyawan kerjakan serta mendorong karyawan untuk bekerja lebih giat dan rajin

3. Pada indikator kuantitas pernyataan, no 3 (tiga) yang menjawab tidak setuju (TS) sebanyak 7 responden atau $1.25 \%$, Dari pernyataan ini penulis dapat memberikan saran karyawan harus memperhatikan

kesempurnaan hasil pekerjaan sehingga memenuhi kuantitas target standar perusahaan.

4. Pada indikator ketepatan waktu pernyataan no 6 (enam) yang menjawab tidak setuju (TS) sebanyak 5 responden atau $12.5 \%$. Dari pernyataan ini penulis dapat memberikan saran karyawan harus selalu bekerja sesuai dengan standar mutu yang telah ditetapkan oleh perusahaan supaya perusahaan dapat mencapai target yang telah di tentukan.

\section{DAFTAR PUSTAKA}

Badriah, Mila. 2015. Manajemen Sumber Daya Manusia. Bandung : CV. Pustaka Setya.

Hasibuan, Malayu. 2011. Manajemen Sumber Daya manusia. Jakarta: PT. Bumi Aksara.

Marwansyah. 2012. Manajemen Sumber Daya manusia. Bandung : Alfabeta.

Siagian, Sondang. P. 2013. Manajemen Sumber Daya Manusia. Jakarta : Gunung Agung

Siswanto, Bejo. 2011. Manajemen Tenaga Kerja Indonesia. "Pendekatan

Administratif dan Operasional". Jakarta : Bumi Aksara.

Sugiyono. 2011. Metode penelitian Kombonasi (Mixed Methods), Bandung: Alfabeta

Sunyoto, Danang. 2015. Manajemen dan Pengembangan Manusia. Yogyakarta : Center For Academic Publishing Service.

Sutrisno, Edy. 2016. Manajemen Sumber Daya Manusia. Jakarta : Kencana.

Sedarmayanti. 2001. Manajemen Sumber Daya Manusia. Reformasi Birokrasi dan Manajemen Pegawai Negeri Sipil, Cetakan Kelima, Bandung: PT Refika 